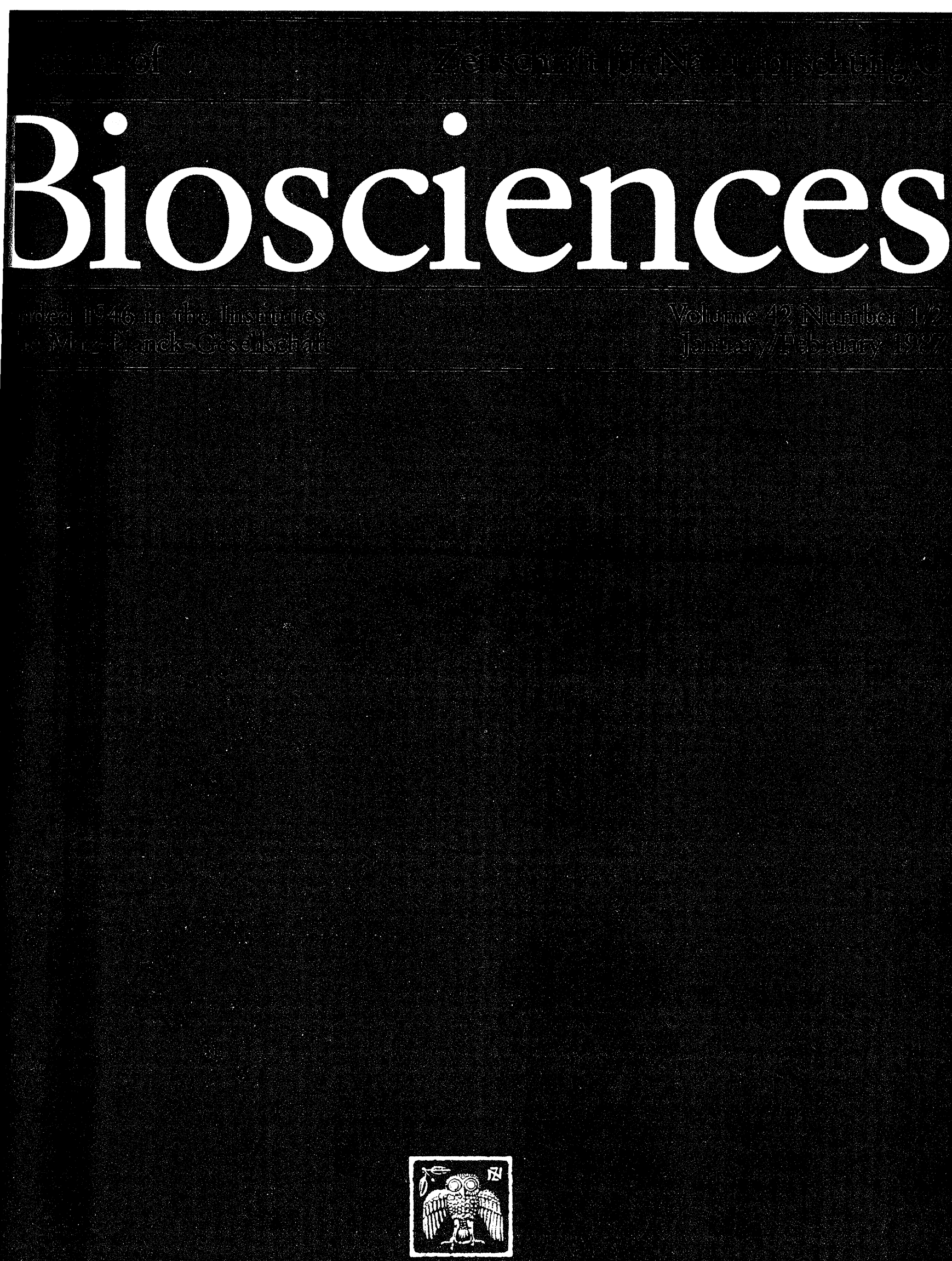




\section{ZEITSCHRIFT FÜR NATURFORSCHUNG}

Section C

A Journal of Biosciences

ISSN 0341-0382

Managing Editor:

H. Hausen, Tübingen

Council:

E. Bünning, Tübingen

A. Butenandt, München

M. Eigen, Göttingen

\section{Editors:}
A. Hager, Tübingen
K. Hahlbrock. Köln
W. Hasselbach, Heidelberg
P. Karlson, Marburg
F. Kaudewitz, München
J. Klein, Tübingen
J. St. Schell, Köln
E. Wecker, Würzburg

\section{Associate Editors:}

N. Amrhein, Bochum

B. A. Askonas, London

W. Barz, Münster

P. Böger, Konstanz

G. Bornkamm, Freiburg

D. Bückmann, Ulm

K. G. Götz, Tübingen

G. Gottschalk, Göttingen

P. Gruss, Heidelberg

G. Isenberg, Köln

R. Jaenicke, Regensburg

V. ter Meulen, Würzburg

G. F. Meyer, Tübingen

M. Rajewsky, Essen

H. Schimassek, Heidelberg

D. Schulte-Frohlinde, Mühlheim/R.

G. Schulz, Freiburg

F. F. Seelig, Tübingen

J. Seelig, Basel

H. Simon, München

W. Steglich, Bonn

H. Stieve, Aachen

J. Suko, Wien

A. Trebst, Bochum

G. Weissenböck, Köln

G. Wick, Innsbruck

V. Zimmermann, Würzburg

\section{Information for Contributors}

Contributions to Z. Naturforsch., Section C (biological sciences), may be (i) original papers, (ii) research notes not exceeding two pages in print and (iii) reports on current research of special interest. Two copies of each contribution should be sent to Dr. Helga Hausen, P. O. Box 2645, D-7400 Tübingen. (Section B (chemical sciences): Dr. Heide Voelter, P.O. Box 2645, D-7400 Tübingen; Section A (physical sciences): Mrs. Tamara Littmann, Lenzhalde 21, D-7082 Oberkochen).

Contributors are encouraged to suggest possible reviewers of their papers. The manuscript should be type written using double spacing throughout.

The title should be concise but informative. The names of the authors, with first names and initials, and of the institution where the work was carried out follow the title. A running title with not more than 60 characters should be indicated if the title is longer than this.

In a footnote on the first page, please give an address for reprint requests.

The title, a selfconsistant abstract, suitable for direct use by the abstracting journals (no references to the main text), and five keywords, all in English, must precede the main text of each contribution.

The main text should meet the highest standards as to novelty of the material, organization and conciseness. A qualified colleague and, if the text is in a foreign language, a person who thoroughly knows it, should have been given the opportunity to check the paper before its submission for publication.

Papers, reporting mainly spectroscopic, X-ray or other data of no general relevancy should not be submitted.

References and footnotes should be numbered (e.g. [1]) and listed at the end of the paper (e.g. [1] A. Meyer, Z. Naturforsch. 30c, 633 (1976)).

Tables with the appropriate captions and a list of the figure legends should follow at the end of the paper.

Allowance should be made for the reduction in printing of the drawings (line thickness, lettering!). Original drawings larger than $21 \times 30 \mathrm{~cm}$ should be replaced by copies of reduced size, when the manuscript is submitted and only be sent in when the manuscript is accepted. On all illustrations, the figure number and the author's name must be written in pencil.

The authors will receive page proofs.

Changes in the text after acceptance of the paper and drawings not fit for direct reproduction cause delay and create extra costs which may be charged to the author. 50 reprints are free of charge.

\section{Information for Subscribers}

The subscription prices per year are for normal subscribers:

$\begin{array}{lll}\text { Section A } & \text { Section B } & \text { Section C } \\ \text { DM 510.- } & \text { DM 610.- } & \text { DM 425.- }\end{array}$

for authors and their institutions if they order directly from the publishers:

$\begin{array}{lll}\text { Section A } & \text { Section B } & \text { Section C } \\ \text { DM 408.- } & \text { DM 488.- } & \text { DM 340.- }\end{array}$

plus postage and handling

$\begin{array}{lll}\text { Section A } & \text { Section B } & \text { Section C } \\ \text { DM 35.- } & \text { DM 35.- } & \text { DM 25.- }\end{array}$

Single copies and back-numbers are available.

Subscriptions will remain standing for the following year unless cancellations are made by postage October 1st.

\section{Informations for Advertisers}

The price for a small advertisement (breadth $43 \mathrm{~mm}$, height $57 \mathrm{~mm}$ ) in all three sections of the journal is DM 60.-.

For larger advertisments please order the price list from the publishers.

VERLAG DER ZEITSCHRIFT FÜR NATURFORSCHUNG, TÜBINGEN

P. O. Box 2645, D-7400 Tübingen (Postscheck-Konto Stuttgart 8039-700). 


\section{ZEITSCHRIFT FÜR}

\section{NATURFORSCHUNG}

\section{SECTION C}

\section{A EUROPEAN JOURNAL OF \\ BIOSCIENCES}

Council

E. BÜNNING,Tübingen

A. ButenandT, München

M. EIGEN, Göttingen
Editorial Board

A. HAGER, Tübingen

K. HAHLBROCK, Köln

W. HASSELBACH, Heidelberg

P. KARLSON, Marburg

F. KAUdEwitz, München

J. KLEIN, Tübingen

J. ST. SCHELL, Köln

E. WeCKER, Würzburg

Advisory Editorial Board

N. Amrhein, Bochum

B. A. Askonas, London

W. BARz, Münster

P. BöGER, Konstanz

G. BornKamm, Freiburg

D. BÜCKMANN, Ulm

K. G. Götz, Tübingen

G. GotTSCHALK, Göttingen

P. GRuss, Heidelberg
G. IsENBERG, Köln

R. JAENICKE, Regensburg

V. TER Meulen, Würzburg

G. F. MEYER, Tübingen

M. RAJEWSKY, Essen

H. SCHIMASSEK, Heidelberg

D. SCHUlte-Frohlinde, Mühlheim/R.

G. SCHULZ, Freiburg

F. F. SeElig, Tübingen
J. Seelig, Basel

H. Simon, München

W. STEGLich, Bonn

H. Stieve, Aachen

J. Suko, Wien

A. Trebst, Bochum

G. WeISSENBöcK, Köln

G. WICK, Innsbruck

V. ZIMMERMANN, Würzburg

EDITED IN COLLABORATION

WITH THE INSTITUTES OF THE MAX-PLANCK-GESELLSCHAFT

\section{VERLAG DER ZEITSCHRIFT FÜR NATURFORSCHUNG TÜBINGEN}


Anschrift des Verlages: Postfach 26 45. D-7400 Tübingen Satz und Druck: Allgäuer Zeitungsverlag GmbH, Kempten

Nachdruck - auch auszugsweise - nur mit schriftlicher Genehmigung des Verlages

Section a

Physics, Physical Chemistry, Cosmic Physics

Section $b$

Inorganic and Organic Chemistry 


\section{Contents}

Contents of Number $1 / 2$

\section{Original Communications}

X-Ray Structure Analysis and Spectroscopic Data of the Antibiotic 8-(Dichloroacetyl)-5-hydroxy-2,7dimethyl-1,4-naphthoquinone from the Fungus Mollisia sp.

G. Weber, T. Hübner, A. Gieren, J. SonnenBICHLER, T. KOWALSKI, and O. HoldENRIEDER 1

Structure of Azadirachtin B

H. REMBot.d, H. Forster, and J. SONNENBICHLER 4

n-Alkylphenols from Schinus terebinthifolius RADDI (Anacardiaceae) (In German)

G. SKopp, H.-J. OPFERKUCH, and G. SCHWENKER 7

Methylation of Guanine in vivo by the Organophosphorus Insecticide Methamidophos

S. M. A. D. ZAYED and F. M. MAHDI

17

Cytogenetic Effects of the Insecticide Methamidophos in Mouse Bone Marrow and Cultured Mouse Spleen Cells

S. M. Amer and M. A. SAYed

Molluscicidal Properties of Quinones (In German)

H. SCHILDKNECHT and J. LUBOSCH

Effects of Plant Bioregulators on the Production of Iridoid Derived Terpenoids in Valeriana wallichii and Fedia cornucopiae Cell Suspension Cultures W. Förster and H. BECKER

Reactions of Substituted Arenediazonium Chlorides with Methylamine-Formaldehyde Premix Revisited: Reactivity and Transformations of Methylolamine Intermediates and Their Biological Significance

G. F. Kolar and M. SCHENDZIELORZ

41

Interaction in vitro of Non-Epithelial Intermediate Filament Proteins with Histones

P. Traub, G. Perides, S. Kühn, and A. ScherBARTH

47
Transformations of trans-2-Hexenal by Botrytis cinerea PERS. as Detoxification Mechanisms (In German)

I. URBASCH

64

Alkaloids in Stem Roots of Nicotiana tabacum and Spartium junceum Transformed by Agrobacterium rhizogenes

M. WINK and L. WITTE

69

Flavonoids from the Leaf Resin of Snakeweed, Gutierrezia sarothrae

D. Hradetzky; E. Wollenweber, and J. N. RoitMAN

The $14 \beta$-Hydroxylation in the Biosynthesis of Cardenolides in Digitalis purpurea. The Role of $3 \beta$ Hydroxy-5 $\beta$-pregn-8(14)-en-20-one

M. E. Deluca, A. M. Seldes, and E. G. Gros 77

Biotransformation of Humulene by Fungi and Enantioselectivity of the Strains Used

W.-R. Abraham and B. StumpF

Enzymatic Synthesis of 1,6-Digalloylglucose from $\beta$ Glucogallin by $\beta$-Glucogallin: $\beta$-Glucogallin $6-0$ Galloyltransferase from Oak Leaves

S. W. Schmidt, K. Denzel, G. Schilling, and G. G. Gross

PAPS-Reductase from Escherichia coli: Characterization of the Enzyme as Probe for Thioredoxins

J. D. SCHWENN and U. SCHRIEK

93

Protein Transport in Chloroplasts: ATP is Prerequisit

C. Schindler, R. Hracky, and J. Soll 103

Lipid Influence on the Structure of the Light Harvesting B 800-850 Proteins

J. Peschke and H. Möhwald

Daffodil Chromoplast DNA: Comparison with Chloroplast DNA, Physical Map, and Gene Localization

P. HANSMANN

118 
Uptake of Protoporphyrin and Violet Light Photodestruction of Propionibacterium acnes

T. B. MeLø

Evolution of $E$. coli tRNA ${ }^{\text {Ile }}$ : Evidence of Derivation from Other tRNAs

M. P. Staves, D. P. Bloch, and J. C. Lacey, Jr.

Intermolecular H-Abstraction of Thiyl Radicals from Thiols and the Intramolecular Complexing of the Thiyl Radical with the Thiol Group in 1,4-Dithiothreitol. A Pulse Radiolysis Study

M. Sh. AkHLaQ and C. von Sonntag

134

The Contents of the Dufour Gland of the Ant Harpagoxenus sublaevis Nyl. (Hymenoptera: Formicidae)

D. G. Ollett, E. D. Morgan, A. B. Atrygalle, and J. P. J. BILLEN

A GC/MS Study of the Propolis Phenolic Constituents

V. Bankova, A. Dyulgerov, S. Popov, and N. MAREKOV

Investigation of the Screening Pigment System in the Compound Eye of the Moth Agrotis segetum (fam. Noctuidae) by Visible Reflectometry

T. Nordtug and T. B. Melø

152

Notes

Epicuticular Leaf Wax of Cistus albanicus, Cistaceae T. VoGT and P.-G. Gülz

Isopulegol from Liquid Cultures of the Fungus Ceratocystis coerulescens (Ascomycotina)

W.-G. KocH and V. SinNWELL

159

Inhibition of cAMP-Phosphodiesterase by Molybdate

B. Ofenloch-HähNLE and K. Eisele

Polyenic Hydrocarbons as Sex Attractants for Geometrids and Amatids (Lepidoptera) Found by Field Screening in Hungary

G. Szöcs, M. Tóth, H. J. Bestmann, O. VostrowsKy, R. R. Heath, and J. H. TuMLINSON
Species and Sex Specificity in the Odour Composition of Two Panurgine Bees (Hymenoptera, Andrenidae)

W. Francke, W. Schröder, A. K. Borg-KarlsSON, G. BergStröm, and J. Tengö

Contents of Number 3

\section{Original Communcations}

Analysis of Single Channel Currents with a Microprocessor Based Device

W. Schreibmayer, E. Hofer, P. Wolf, A. Lueger, and H. A. Tritthart 173

Natural Waxes Investigated by Soft Ionization Mass Spectrometry

H.-R. Schulten, K. E. Murray, and N. Simmi.eit

Epicuticular Leaf Wax of Euphorbia dendroides L.. Euphorbiaceae

P.-G. Gül.z, H. Hemmers, J. Bodden, and F.-J. MARNER

191

Cell-Free Synthesis of the Alkaloids Ammodendrine and Smipine

M. WINK and L. WITTE

Comparison of the Solid State CPMAS and Solution Carbon-13-NMR Spectra of Humic Acids Extracted from Composted Municipal Refuse

R. Fründ, F. J. Gonzalez-Vila, H.-D. LüdeMANN, and F. MARTIN

205

Glutamic Acid-1-semialdehyde, a Hypothetical Intermediate in the Biosynthesis of 5-Aminolevulinic Acid
A. KAH and D. DörnemanN
209

Interaction of Sodium, Lithium, Caesium, and Potassium Ions with Ascorbyl Radicals

P. WieCZOREK, T. OgOŃSKI, and Z. MACHOY

The Effect of Guanidinium Chloride on the SelfAssociation of Bovine Liver Glutamate Dehydrogenase: a Gel Filtration Study

A. MAZzinI and R. FAvilla

217 
Molecular Mechanics Investigation on Side-Chain Conformations of a $17 \alpha$-Ethyl-17 $\beta$-hydroxy Steroid with Regard to Receptor Binding M. BOHL

Characterization and Amino Acid Composition of a Hypertrehalosaemic Neuropeptide from the Corpora cardiaca of the Cockroach, Nauphoeta cinerea

G. GÄDE

The Rate of ATP Hydrolysis Catalyzed by Reconstituted $\mathrm{CF}_{0} \mathrm{~F}_{1}$-Liposomes

G. SCHMIDT and P. GRÄBER

Phosphate Accumulation by Muscle in vitro and the Influence of Vitamin $D_{3}$ Metabolites

T. BELLIDO and R. BOLAND

A Correlation between Detergent Tolerance and Cell Wall Structure in Green Algae

S. Biedlingmaier, G. Wanner, and A. Schmidt

Further Characterization of Chickpea Isoflavone 7 O-Glucoside-6"-O-malonate : malonylesterase:

Evidence for a Highly Specific, Membrane-Bound Enzyme in Roots of Cicer arietinum L.

W. Hinderer, J. Köster, and W. Barz

Chromophore Assignment in C-Phycocyanin from Mastigocladus laminosus

S. Siebzehnrübl., R. Fischer, and H. Scheer 258

The Effect of Phosphinothricin (Glufosinate) on Photosynthesis. I. Inhibition of Photosynthesis and Accumulation of Ammonia

A. Wild, H. Sauer, and W. Rühle

263

The Effect of Phosphinothricin (Glufosinate) on Photosynthesis. II. The Causes of Inhibition of Photosynthesis

H. Sauer, A. Wild, and W. Rühle

Sethoxydim-Uptake by Leaf Slices of Sethoxydim Resistant and Sensitive Grasses

I. Struve, B. Golle, and U. Lüttge

Light-Induced $\mathrm{Ca}^{2+}$ Influx into Spinach Protoplasts K. Heimann, G. Kreimer, M. Melkonian, and E. LATZKO

283

Acyclonucleoside Analogues Consisting of 5- and 5,6-Substituted Uracils and Different Acyclic
Chains: Inhibitory Properties vs Purified E. coli Uridine Phosphorylase

A. K. Drabikowska, L. Lissowska, M. DraminSKI, A. Zgit-WroblewsKa, and D. Shugar 288

A Simple Analysis of Purine and Pyrimidine Nucleotides in Plant Cells by High-Performance Liquid Chromatography

H. Ashihara, K. Mitsui, and T. Ukaji

Magnetotactic Bacteria from Freshwater

M. Oberhack, R. Süssmuth, and H. Frank

300

\section{Contents of Number 4}

\section{Original Communications}

Stereochemistry and Mechanism of Reactions Catalyzed by Tyrosine Phenol-Lyase from Escherichia intermedia

M. M. Palcic, S.-J. Shen, E. Schleicher, H. Kumagai, S. Sawada, H. Yamada, and H. G. FLoss

307

Distant Precursors of Benzylisoquinoline Alkaloids and Their Enzymatic Formation

M. RUEFFER and M. H. ZENK

Characterization of $2 \beta(R)-17-\mathrm{O}-$ Acetylajmalan: Acetylesterase - a Specific Enzyme Involved in the Biosynthesis of the Rauwolfia Alkaloid Ajmaline

L. Polz, H. SchÜBeL, and J. StöcKigT

333

Induction and Characterization of a NADPH-Dependent Flavone Synthase from Cell Cultures of Soybean

G. Kochs and H. Grisebach

Proposal for the Mechanism of Action of Urocanase. Inference from the Inhibition by 2-Methylurocanate

E. GERLINGER and J. RÉTEY

349

Re-Investigation of the Protein Structure of Coenzyme $B_{12}$-Dependent Diol Dehydrase

K. Tanizawa, N. Nakajima, T. Toraya, H. Tana$\mathrm{KA}$, and K. SODA

353 
Methanogenesis from Acetate by Methanosarcina barkeri: Catalysis of Acetate Formation from Methyl Iodide, $\mathrm{CO}_{2}$, and $\mathrm{H}_{2}$ by the Enzyme System Involved

K. Laufer, B. Eikmanns, U. Frimmer, and R. K. THAUER 360

Divergent Evolution of $5 \mathrm{~S}$ rRNA Genes in Methanococcus

G. WICH, L. SibOLD, and A. BöcK

Characterization of Some Claviceps Strains Derived from Regenerated Protoplasts

B. SchumanN, W. Maier, and D. Gröger 381

Phenylalanine and Tyrosine Biosynthesis in Sporeforming Members of the Order Actinomycetales H.-K. Hund, B. Keller, and F. Lingens

E. coli Maltodextrin Phosphorylase: Primary Structure and Deletion Mapping of the C-Terminal Site D. Palm, R. Goerl, G. Weidinger, R. Zeier, B. FisCHER, and R. SCHINZEL

Fermentation of D-Xylose to Ethanol by Bacillus macerans

H.-J. Schepers, St. Bringer-Meyer, and H. Sahm

Semicontinuous and Continuous Production of Citric Acid with Immobilized Cells of Aspergillus niger H. EIKMEIER and H. J. ReHM 408

Microbial Hydroxylation of Cedrol and Cedrene W.-R. Abraham, P. Washausen, and K. KIESLICH

6-Methylpurine, 6-Methyl-9- $\beta$-D-ribofuranosylpurine, and 6-Hydroxymethyl-9- $\beta$-D-ribofuranosylpurine as Antiviral Metabolites of Collybia maculata (Basidiomycetes)

K. Leonhardt, T. Anke, E. Hillen-Maske, and W. STEGLICH

Enzymatic Synthesis of Riboflavin and FMN Specifically Labeled with ${ }^{13} \mathrm{C}$ in the Xylene Ring H. Sedlmaier, F. Müller, P. J. Keller, and A. BACHER

A Vitamin $D_{3}$ Steroid Hormone in the Calcinogenic Grass Trisetum flavescens W. A. Rambeck, H. Weiser, and H. Zucker 430
Functional Group Recognition of Pheromone Molecules by Sensory Cells of Antheraea polyphemus and Antheraea pernyi (Lepidoptera: Saturniidae) H. J. Bestmann, W. Cai-Hong, B. Döhla, LiKedong, and K. E. Kaissling

Building Blocks for Oligonucleotide Syntheses with Uniformly Fragmentable $\beta$-Halogenated Protecting Groups (In German)

P. Lemmen, R. Karl, I. Ugi, N. Balgobin, and J.

ChatTopadhyaya

Experiments on the Optical Resolution of Conduramine Analogs by Enzymatic Transesterification in Organic Solvents (In German)

G. KRESZE and M. SABUNI

Steric Course of the Rhodium-Catalyzed Decarbonylation of Chiral 4-Methyl- $\left[1-{ }^{3} \mathrm{H}, 2-{ }^{2} \mathrm{H}_{1}\right]$ pentanal

H. Otsuka and H. G. Floss

Synthesis of Immobilized Peptide Fragments on Polystyrene-Polyoxyethylene for Affinity Chromatography (In German)

E. BAyer, H. Hellstern, and H. Eckstein

455

Biopterin Synthesis in Mouse Spleen during Bone Marrow Transplantation Correlates with Unimpaired Hemopoietic Engraftment

I. ZIEGLER and ST. THIERFELDER

461

In vivo Screening of Glutathione Related Detoxification Products in the Early State of Drug Development

A. Prox, J. Schmid, J. Nickl, and G. EngelHARDT

465

Synthesis and Complexing Features of an Artificial Receptor for Biogenic Amines (In German)

F. P. SCHMIDTCHEN

Metabolism of the Herbicide 2-(2,4-Dichlorophenoxy)-propionic Acid (Dichlorprop) in Barley (Hordeum vulgare)

G. Bärenwald, B. Schneider, and H.-R. SCHÜTTE

486

Site Directed Antisera to the D-2 Polypeptide Subunit of Photosystem II

R. Geiger, R. J. Berzborn, B. Depka, W. OettMEIER, and A. TREBST 
Contents of Number 5

\section{Original Communications}

Epicuticular Wax Hydrocarbons of Ericaceae in Germany

I. SALASOO

On the Essential Oils from Chrysanthemum balsamita L. (In German)

H. Strobel, K. KNobloch, and E. Ziegler 502

Epoxy-trans-isodihydrorhodophytin, a New Metabolit from Laurencia obtusa (In German)

S. Imre, H. Lotter, H. Wagner, and R. H. THOMSON

Structure Elucidation of Kwakhurin, a New Prenylated Isoflavone from Pueraria mirifica Roots

S. Tahara, J. L. Ingham, and S. Z. Dziedzic 510

Biosynthesis of Vitexin and Isovitexin: Enzymatic Synthesis of the C-Glucosylflavones Vitexin and Isovitexin with an Enzyme Preparation from Fagopyrum esculentum M. Seedlings

F. KERSCHER and G. Franz

Effect of $\mathrm{pH}$ on Glycolate and Ammonia Excretion in L-MSO Treated Chlorella Cells

Y. Shiraiwa and G. H. SCHMid

Derepression of Arylsulfatase Activity by Sulfate Starvation in Chlorella fusca

I. Niedermeyer, S. Biedlingmaier, and A. SCHMIDT

Root Hair Specific Proteins in Glycine max

D. WERNER and A. B. WOLFF

Synthesis, Analysis and Characterization of the Coenzyme A Esters of $o$-Succinylbenzoic Acid, an Intermediate in Vitamin $\mathrm{K}_{2}$ (Menaquinone) Biosynthesis

R. Kolkmann and E. Leistner

Chloride Availability Affects the Malate Content and its Control by the Circadian Clock in Pulvini of Phaseolus coccineus L.

W.-E. Mayer, W. A. Ruge, N. Starrach, and R. HAMPP

553
Enzymatic Acyloin Condensation of Acyclic Aldehydes

W.-R. Abraham and B. StumpF

559

Sn-Glycerol-3-phosphate is a Product of Starch Degradation in Isolated Chloroplasts from Chlamydomonas reinhardii

G. KLöcK and K. KREUZBERG

567

Substrate Flow from Photosynthetic Carbon Metabolism to Chloroplast Isoprenoid Synthesis in Spinach Evidence for a Plastidic Phosphoglycerate Mutase

D. Schulze-Siebert, A. Heintze, and G. SCHULTZ 570

Energy-Dependent Chlorophyll Fluorescence Quenching in Chloroplasts Correlated with Quantum Yield of Photosynthesis

G. H. Krause and H. LaAsch 581

Spontaneous Release of Malondialdehyde from Ultraviolet Light Exposed Liposomal Membranes S. Agarwal, A. Ghosh, and S. N. Chatterjee

Pyrimidine Homoribonucleosides: Synthesis, Solution Conformation, and Some Biological Properties

P. Lassota, J. T. Kusmierek, R. Stolarski, and D. SHUGar 589

Reactivation of Streptolysin S by Oligonucleotide

A. TAKETO and Y. TAKETO

599

Ring Opening Reactions of Bioreactive Lactam Systems (In German)

H. Frister and E. SCHLimme

Embryotoxicity Induced by Alkylating Agents. Some Methodological Aspects of DNA Alkylation Studies in Murine Embryos Using Ethylmethanesulfonate

T. Pl.Atzek, G. Bochert, U. Rahm, and D. NeUbert

Tetraponerine-8, an Alkaloidal Contact Poison in a Neoguinean Pseudomyrmecine Ant, Tetraponera sp.

J. C. Braekman, D. Daloze, J. M. Pasteels, P. van Hecke, J. P. DeclercQ, V. Sinnwell, and W. FRANCKE 


\section{Contents of Number $7 / 8$}

\section{Original Communications}

ZZE-Configuration of Chromophore $\beta-153$ in CPhycocyanin from Mastigocladus laminosus G. Schmidt, S. Siebzehnrübl, R. Fischer, W. Rüdiger, H. Scheer, T. Schirmer, W. Bodf, and R. HUBER

$\alpha$-Diceroptene: A New Dimeric Structure for Isoceroptene

Ch. Vilain, A. Hubert, L. Dupont, K. R. MarkHAM, and E. WOLLENWEBER

849

Stereochemistry of Two Hydroxybiflavanonols from Garcinia cola Nuts

J. Sonnenbichler, I. Madubunyi, and H. Scheer

"Epicuticular Waxes" from Exine Material of Pine Pollen

Ch. Niester, P.-G. Gülz, and R. Wiermann 858

Bryoflavone and Heterobryoflavone. Two New Isoflavone-flavone Dimers from Bryum capillare H. Geiger, W. Stein, R. Mues, and H. D. ZinsMEISTER

Site of Lupanine and Sparteine Biosynthesis in Intact Plants and in vitro Organ Cultures

M. WINK

868

Occurrence of Amavadin in Mushrooms of the Genus Amanita (In German)

E. $\mathrm{KoCH}, \mathrm{H}$. KNEIFEL, and E. BAyer

Ascorbic Acid and Glutathione Contents of Spruce Needles from Different Locations in Bavaria W. F. Osswald. H. Senger, and F. E. Elstner

Acetyl-CoA:4-Hydroxybutinylbithiophene O-Acetyltransferase Isoenzymes from Tagetes patula Seedlings

G. Metschulat and R. Sütfeld

885

Uptake and Utilization of Sulfonic Acids in the Cyanobacterial Strains Anabaena variabilis and Plectonema 73110

S. Biedlingmaier and A. SCHMIDT
Partial Characterization of an Enzyme from the Fungus Ascochyta rabiei for the Reductive Cleavage of Pterocarpan Phytoalexins to 2'-Hydroxyisoflavans

B. HöHL and W. BARZ

897

Comparing Short-Term Effects of Ammonia and Methylamine on Nitrogenase Activity in Anabaena variabilis (ATCC 29413)

S. Reich, H. Almon, and P. Böger

902

Reversible pH-Induced Dissociation of Glucose Dehydrogenase from Bacillus megaterium. II. Kinetics and Mechanism

E. Maurer and G. Pfleiderer

On the Possible Relation between Morphology and Precursors of the Crystallities in Calcified Tissues F. C. M. Driessens, R. A. Terpstra, P. BenneMA, J. H. M. WÖl.tGENS, and R. M. H. VERBEECK

916

In the Search for New Anticancer Drugs, XXI. Spin Labeled Nitrosoureas

G. Sosnovsky, S. W. LI, and N. U. M. RaO

Transmission of Hormonal Imprinting in Tetrahymena Cultures by Intercellular Communication

G. CSABA and P. Kovács

932

MTD Calculations on Quantitative Structure-Activity Relationships of Steroids Binding to the Progesterone Receptor

M. Bohl, Z. Simon. A. Vlad, G. Kaufmann, and

K. PONSOLD

935

Synthesis of Heat Shock Proteins during Amino Acid or Oxygen Limitation in Bacillus subtilis rel $A^{-}$and relA (In German)

M. Hecker, A. Richter, A. Schroeter, L. WölFEL, and F. MACH

Sexual Pheromones and Related Egg Secretions in Laminariales (Phaeophyta)

I. Maier, D. G. Müller, G. Gassmann, W. BoLAND, and L. JAENICKE

948

Comparison of Dufour Gland Secretions of Two Species of Leptothorax Ants (Hymenoptera: Formicidae)

M. F. Ali, E. D. Morgan, A. B. Attygalite, and J. P. J. BILleN 955 
Comparative Sex Pheromone Biosynthesis in the Obliquebanded Leafroller, Choristoneura rosaceana, and the Redbanded Leafroller, Argyrotaenia velutinana, Moths

St. P. Foster and W. L. Roelofs

961

Effect of Hydroxylamine Derivatives on Photorespiration in the Tobacco Aurea Mutant Nicotiana tabacum $\mathrm{Su} / \mathrm{su}$

G. H. Schmid, K. P. Bader, A. Radunz, C. J. van Assche, N. Reinier, and B. Courtiade 965

Estimation of the Extent of DNA Platination after Interaction of cis-DDP with DNA and Chromatin I. KuLAMOWICZ and Z. WALTER 970

Reversed Light Reaction of the Screening Pigment in a Compound Eye Induced by Noradrenaline

A. Juse, G. Höglund, and K. Hamdorf

973

Light and Electron Microscopic Studies Regarding Cell Contractility and Cell Coupling in Light Sensitive Smooth Muscle Cells from the Isolated Frog Iris Sphincter

K. V. Wol.F

Fluorescence Monitoring of Membrane Potentials: the Spatio-Temporal Resolution in Isolated Neurons of Helix pomatia

Th. KNÖPFEL and P. Fromherz

986

Growth Kinetics of the G2-Phase of Ehrlich Ascites Tumor Cells, Separated from Anaerobically Treated Asynchronous Cultures

C. Kroll, W. Kroll, and F. Schneider

Demonstration of Statistically Significant Correlations between 8 and $12 \mathrm{kHz}$ Atmosferics and Sudden Deafness

G. Ruhfenstroth-Bauer, K. Mees, R. SandhaGeN, H. BAUmer, and B. Filipiak

999

Notes

$\gamma$-Decalactone, an Odoriferous Compound from the Male Butterfly, Lethe marginalis Motschulsky

N. Hayashi, H. Kawaguchi, A. Nishi, and H. KOMAE

1001

The Phosphatidylinositol Species of Suspension Cultured Plant Cells

S. Heim and K. G. WAGNeR

1003
Are Small RNAs Associated with Crohn's Disease?

R. Pechan, H. Kunert, and H. J. Gross 1006

Inhibition of cAMP Phosphodiesterase by Some Phototherapeutic Agents

L. Bovalini, P. Lusini, S. Simoni, D. Vedaldi, L. Andreassi, F. Dall'Acqua, and P. Martelli

Report

Chimeric Genes - Their Contribution for Molecular Biology and Plant Breeding (In German)

H.-H. Steinbiss and J. Schell.

1011

Contents of Number $9 / 10$

\section{Original Communications}

Terpenoids from a Black Sea Bryozoan Conopeum seuratum

P. Hadjeva, S. Popov, B. Budevska, A. DyulGEROV, and S. ANDREEV

1019

Thin Layer Chromatographic and Infra Red Spectral Evidence for the Presence of Phosphonolipids in Cicada oni

M. C. Moschidis

Adnexal Glands Chemistry of Messor ebeninus Forel (Formicidae: Myrmicinae)

M. Coli. A. Hefetz, and H. A. Lloyd

1027

A Novel Caffeic Acid Derivative and Other Constituents of Populus Bud Excretion and Propolis (Bee-Glue)

E. Wollenweber, Y. Asakawa, D. Schillo, U. LEHMANN, and H. Weigel

1030

Polyunsaturated Pheromones: Semi-Synthesis of $(Z, Z)-6,9$-Alkadienes and $(Z, Z, Z)-3,6,9$-Alkatrienes from Naturally Occurring Fatty Acids

H. K. Mangold, H. Becker, and E. Schulte

NMR Spectra of Flavone Di-C-glycosides from Apometzgeria pubescens and the Detection of Rotational Isomerism in 8-C-Hexosylflavones K. R. Markham, R. Mues, M. Stoll, and H. D. ZINSMEISTER

1039 
Trichothecene Mycotoxins from Fusarium culmorum Cultures

N. C. P. Baldwin, B. W. Bycroft, P. M. Dewick, D. C. Marsh, and J. Gilbert 1043

Metabolism of the Prenylated Pterocarpan Edunol by Aspergillus flavus

S. TAHARA and J. L. INGHAM

1050

Fungal Metabolism of the Prenylated Isoflavone 2,3Dehydrokievitone

S. Tahara, E. Misumi, J. Mizutani, and J. L. INGHAM

1055

Novel Flavonoids from the Fern Notholaena sulphurea

F. J. Arriaga-Giner, M. Iinuma, T. Tanaka, M. Mizuno, C. Scheele, and E. Wollenweber 1063

Synthesis of Piperoyl Coenzyme A Thioester U. Semler, G. Schmidtberg, and G. G. Gross

Geraniol-10-hydroxylase Activity and Its Relation to Monoterpene Indole Alkaloid Accumulation in Cell Suspension Cultures of Catharanthus roseus O. Schiel, L. Witte, and J. Berlin

1075

A New Detection Procedure for Aminoacylase Activity of Microorganisms Directly on Plate Culture with $o$-Phthalaldehyde (In German)

Y. Yamazaki, W. Hummel, and M.-R. Kula

1082

Small Angle X-Ray Study on the Structure of Active and Inactive Ribulose-1,5-bisphosphate Carboxylase-Oxygenase from Spinach. Evidence for a Configurational Change

I. Pilz, E. Schwarz, G. P. Pal, and W. Saenger 1089

Quantitative Histochemical Analysis of Starch, Malate and $\mathrm{K}^{+}$, together with the Activity of Phospho-enolpyruvate Carboxylase along an Elongating Primary Leaf of Hordeum vulgare

R. Hampp, W. H. Outlaw Jr., and H. ZiegleR

1092

Biotransformation of Citral by Botrytis cinerea P. Brunerie, I. Benda, G. Bock, and P. Schreier
Comparison of Various Strategies Designed to Optimize Indole Alkaloid Accumulation of a Cell Suspension Culture of Catharanthus roseus J. Berlin, Ch. Mollenschott, and F. DiCosmo

1101

Amperometric Titration Largely Overestimates Chloride Concentrations in Chloroplast Extracts

G. SCHRÖPPEL-MEIER and W. M. KaISER

1109

Extrachloroplastic Site of Synthesis of Three Chloroplast Proteins in Maize (Zea mays)

L. A. Kleczkowski, C. A. Zeiher, and D. D. RANDALL

1113

Organolead Toxicity in Plants: Triethyl Lead $\left(\mathrm{Et}_{3} \mathrm{~Pb}^{+}\right)$Acts as a Powerful Transmembrane $\mathrm{Cl}^{-} /$ $\mathrm{OH}^{-}$Exchanger Dissipating $\mathrm{H}^{+}$-Gradients at Nano-Molar Levels

A. Hager, I. Moser, and W. Berthold 1116

Effect of $\mathrm{pH}$ on the Slow Phase Components of Delayed Luminescence in Chloroplasts

E. Hideg and S. Demeter

Chemokinesis and Necrotaxis of Human Granulocytes: the Important Cellular Organelles

H. Gruler and A. De Boisfleury Chevance 1126

In vitro $\mathrm{T}_{1}$ and $\mathrm{T}_{2}$ Relaxation Times of Coagulating Blood and Thrombuses (In German)

U. M. Landler, K. Hergan, E. Justich, and H. STERK

1135

Dependence of a Sleeping Parameter from the N-S or E-W Sleeping Direction

G. Ruhenstroth-Bauer, E. Rüther, and Th.

REINERTSHOFER

1140

Notes

Automatic Turgor Pressure Recording in Plant Cells K.-H. Büchner, G. Wehner, W. Virsik, and U. ZIMMERMANN

1143

Distinct Substrate Specificity of Dihydroflavonol 4-Reductase from Flowers of Petunia hybrida G. Forkmann and B. RuhnaU 1146

Erratum 
Contents of Number $11 / 12$

Contents of Nos 1-12

III-XIV

\section{Original Communications}

Identification of Betulin in Archaeological Tar (In German)

F. Sauter, E. W. H. Hayek, W. Moche, and U. JORDIS

1151

Chemical Composition and Morphology of Epicuticular Waxes from Leaves of Solanum tuberosum

A. SEN

1153

Asymmetric Reduction of 4(5)-Oxocarboxylic Acids by Baker's Yeast (In German)

M. Gessner, C. Günther, and A. Mosandl. 1159

Partial Lack of N-Acetyl Substitution of Glucosamine in the Peptidoglycan of the Budding Phototrophic Rhodomicrobium vannielii

U. J. Jürgens, B. Rieth, J. Weckesser. C. S. Dow, and W. A. KöNIG

1165

Accumulation of Phenolic Compounds and Phytoalexins in Sliced and Elicitor-Treated Cotyledons of Cicer arietinum L.

U. Jaques, H. Kessmann, and W. Barz

Natural Inhibitors of Germination and Growth IV Compounds from Fruit and Seeds of Mountain Ash (Sorbus aucuparia)

U. Oster, I. Blos, and W. Rüdiger

The $v$ versus $v[I]$ Plot
A. C. Borstlap

1185

Development of New Plate Tests for the Detection of Microbial Hydrolysis of Esters and Oxidations of 2-Hydroxycarboxylic Acids (In German)

Y. Yamazaki and M.-R. Kul.a

Enzymatic Synthesis of $4^{\prime}$ - and $3^{\prime}, 4^{\prime}$-Hydroxylated Flavanones and Flavones with Flower Extracts of Sinningia cardinalis

K. STICH and G. ForkmanN

1193

Purification and Properties of Chalcone Synthase from Cell Suspension Cultures of Soybean

R. Welle and H. Grisebach

1200
4-(2'-Carboxyphenyl)-4-oxobutyryl Coenzyme A Ester, an Intermediate in Vitamin $\mathrm{K}_{2}$ (Menaquinone) Biosynthesis

R. Kolkmann and E. Leistner

1207

Role of Pyrophosphate: Fructose-6-phosphate 1-Phosphotransferase in Glycolysis in Cultured Catharanthus roseus Cells

H. Ashihara and T. Horikosi

The Separation of Two Different Enzymes Catalyzing the Formation of Hydroxycinnamic Acid Glucosides and Esters

P. A. Bäumker, M. Jütte, and R. Wiermann 1223

Protein Sequence and Structure of N-Terminal Amino Acids of Subunit Delta of Spinach Photosynthetic ATP-Synthase CF,

R. J. Berzborn, W. Finke, J. Otto, and H. E. MEYER

1231

Isolation and Characterization of a Supramolecular Complex of Subunit III of the ATP-Synthase from Chloroplasts

P. Fromme, E. J. Boekema, and P. Gräber 1239

The Polyphasic Rise of Chlorophyll Fluorescence upon Onset of Strong Continuous Illumination: I. Saturation Characteristics and Partial Control by the Photosystem II Acceptor Side

$\mathrm{Ch}$. Neubauer and U. Schreiber

1246

The Polyphasic Rise of Chlorophyll Fluorescence upon Onset of Strong Continuous Illumination: II. Partial Control by the Photosystem II Donor Side and Possible Ways of Interpretation

U. Schreiber and $\mathrm{Ch}$. Neubauer

1255

Benzofuroxan as Electron Acceptor at Photosystem I B. Lotina-Hennsen, A. Garcia, M. Aguil.ar, and M. Albores

1265

CARS Investigation of Changes in Chromophore Geometry of C-Phycocyanin from Mastigocladus laminosus Induced by Titration with $p$-Chloromercuribenzenesulfonate

S. SChNeider, F. BAumanN, and U. KlüTeR

1269

Inhibition by Sethoxydim of Pigment Accumulation and Fatty Acid Biosynthesis in Chloroplasts of Avena Seedlings

H. K. Lichtenthaler, K. Kobek, and K. IshiI

1275 
Bioenergetics Studies of the Cyanobacterium Anabaena variabilis

S. Schirer, H. SAdowski, and P. Böger

1280

Radiochemical Methods for Studying Lipase-Catalyzed Interesterification of Lipids

R. Schuch and K. D. MukherJeE

1285

cAMP-Dependent Protein Kinase Activity in Yeast Mitochondria

G. Mül.LER and W. Bandi.ow

1291

Twisted Fibrils are a Structural Principle in the Assembly of Interstitial Collagens. Chordae Tendineae Included

W. Folkhard, D. Christmann, W. Geercken. E. Knörzer. M. H. J. Koch, E. Mosi.er. H. Nemetschek-Gansler, and T. Nemetschl:k 1303

Lysine Decarboxylase from Hafnia alvei: Purification, Molecular Data and Preparation of Polyclonal Antibodies

H. Bialer, L. F. Fi:CKER, and J. BERIIN

1.307

Recognition of HLA Class II Molecules by Antipeptide Antibodies Elicited by Synthetic Peptides Selected from Regions of HLA-DP Antigens

A. Chirsi, R. A. Houghten, M. C. Morganti. and E. Muratti

1313

Active Cyanogenesis - in Zygaenids and Other Lepidoptera

K. Witthohn and C. M. Naumann

Efficacy of Sustained-Release Radioprotective Drugs in vivo

J. Shanl. S. Benita, M. Abdulrazik, and A. Yerushalmi

1323

MHC-Antigens: Constituents of the Envelopes of Human and Simian Immunodeficiency Viruses

H. Gelderblom. H. Reupke. T. Winkfi.

R. Kunze. and G. Pauli

1328

Evidences for Circadian Rhythmicity in the per" Mutant of Drosophila melanogaster

$\mathrm{CH}$. Hei.frich and W. EngfimanN

1335

\section{Notes}

Conformational Changes in Proteins Induced by Low Temperatures: an Infrared Study H. L. Casal. U. Köhl.er. H. H. Mantsch. F. M. GoÑı. and J. L. R. Arrondo

1.339
Thermal Lability of Membrane Proteins of Age Separated Erythrocytes as Studied by Electron Spin Resonance Spin Label Technique

G. Bartosz, G. Christ. H. Bossf. R. Stephan, and H. GäRTNER

Lipids in the Gular Gland Secretion of the American Alligator (Alligator mississippiensis)

P. J. Weidon. A. Shafagati, and J. W. Whitiler

Identification of the Sex Pheromone of Eggplant Borer Leucinodes orbonalis Guenèe (Lepidoptera: Pyralidae)

Zhu Pingchou, Kong Fanlei, Yu Shengd, Yu Yongqing, Jin Shuping. Hu Xinhua, and Yu JianWEI

1347

(Z)-5-Dodecen-1-ol. Another Inhibitor of Pheromonal Attraction in Coleophora laricella

E. PriEsnt:R

(Z)-3-Tetradecenyl Acetate as a Sex-Attractant Component in Gelechiinae and Anomologinate (Lepidoptera: Gelechiidae)

E. Priesni:R

1352

Mammalian Pheromone Studies. VI. Compounds from the Preorbital Gland of the Blue Duiker. Cephalophus monticola

B. V. Burger and P. J. Pretorius

1355

Structural Features and Biological Functions in Blue Copper Proteins

Y. NISHIDA

1.358

Inhibition of the Acetyl-CoA Carboxylase of Barley' Chloroplasts by Cycloxydim and Sethoxydim

M. Focke and H. K. Lichtenthai.F:R

1361

Formation of Large Thioredoxin $f$ Accompanics Chloroplast Development in Scenedesmus obliquuls

P. Langiotz and H. Folimann

1364

Cellular Spin Resonance of Yeast in a Frequency Range up to $140 \mathrm{MHz}$

R. HöI.ZFI. and I. LAM PRF.CHT

1367

Melting Pressure. Volume and Stability of Blood at High Pressure (In German)

A. Ki.uge and H. LentZ

Subjekt Index

1373

Authors Index

140.3 


\title{
Chromophore Assignment in C-Phycocyanin from Mastigocladus laminosus
}

\author{
S. Siebzehnrübl, R. Fischer, and H. Scheer \\ Botanisches Institut der Universität München, Menzinger Straße 47, \\ D-8000 München 19, Bundesrepublik Deutschland
}

Z. Naturforsch. 42c, 258-262 (1987); received November 4, 1986

Photosynthesis, Cyanobacteria, Energy Transfer, Antenna Pigments, Cystein Modification

C-phycocyanin from the cyanobacterium, Mastigocladus laminosus, and its subunits have been treated with $p$-chloromercuribenzenesulfonate (PCMS). A single reactive site was found on the $\beta$ subunit, and assigned to the single free cystein- $\beta 109$. The concomitant spectral changes (absorption, fluorescence, circular dichroism), together with the known close proximity of cys- $\beta 109$ to chromophore $\beta 82$, allowed an unambiguous assignment of the three spectrally, biochemically and functionally different chromophores to specific binding sites on the two peptide chains ( $\alpha 84$ : $616-618, \beta 82: 622-624, \beta 153: 598-600 \mathrm{~nm})$.

\section{Introduction}

C-phycocyanins (PC), the light-harvesting pigments from cyanobacteria, are composed of two subunits $(\alpha, \beta)$ bearing one and two open-chain tetrapyrrolic chromophores, respectively $[1-5]$. In spite of their common structures $[1,2,6,7]$, the three chromophores differ in their spectroscopic properties $[8-10]$ and their reactivities $[10-12]$. These differences, which arise from the different environments of the individual chromophores in the native chromoprotein, are essential for the fine tuning of their biological functions $[1-5,8,10,13]$.

The individual environments and conformations of the three chromophores, have recently been mapped in detail by sequenation [14-19] and X-ray crystallography $[20,21]$. The data indicate a considerable degree of homology around the respective chromophores in PC's from different organisms. The single chromophore on the $\alpha$-subunit is attached to Cys- 84 , and the chromophores on the $\beta$-subunit to Cys- 82 and Cys-153. The two PC's studied by high-resolution X-ray crystallography $[20,21]$ (from Mastigocladus laminosus and Agmenellum quadruplicatum), have furthermore almost identical chromophore and protein conformations and differ only in their aggregation state.

A correlation between the spectrally and structurally distinct chromophores has hitherto been lacking, but is very important in view of the recent progress in energy transfer studies (see e.g. [13]). Based on the

Reprint requests to Prof. Dr. H. Scheer.

Verlag der Zeitschrift für Naturforschung, D-7400 Tübingen 0341-0382/87/0300-0258 \$01.30/0 observation of a single binding site (cys- $\beta 109$ ) for mercurials $[20,21]$, we have now titrated PC and its subunits from $M$. laminosus with the thiol reagent, PCMS, which led to the unambiguous assignment of the chromophores. This situation is more clear-cut than in other biliproteins, e.g. phycoerythrin [22] containing more than a single free cystein available for reaction with mercurials [1-5].

\section{Materials and Methods}

M. laminosus was grown in Castenholz medium [23] in 3001 batch cultures [24] and provided to us and stored deep frozen. PC and the subunits were prepared as described previously [6]. $p$-Chloro-mercuri-benzenesulfonic acid (PCMS, Aldrich) was a gift of $T$. Schirmer, all other chemicals came from Merck (Darmstadt).

Absorption spectra were recorded on a model 8451 A spectrophotometer (Hewlett-Packard), fluorescence spectra on a model DMR22 fluorimeter (Zeiss, Oberkochen) and circular dichroism spectra on a model $\mathrm{V}$ dichrograph (Jobin-Yvon, Unterhaching).

Titrations were carried out by adding aliquots of a stock solution of PCMS ( $2.26 \mathrm{~mm}$, in potasium phosphate buffer, $100 \mathrm{~mm}, \mathrm{pH} 7.0$ ) to the chromoprotein solutions (1-3 $\mu \mathrm{M}$ in the same buffer). The following extinction coefficients were used for the concentration determinations: PC trimer $=870,000 \mathrm{~cm}^{2} \mathrm{M}^{-1}$ corresponding to 290,000 per protomer $(\alpha \beta)_{1}$ and 97,000 per chromophore); $\beta$-subunit $=164,000$ corresponding to 82,000 per chromophore; $\alpha$-subunit $=122,000$. They were determined by unfolding 
the proteins with $8 \mathrm{~m}$ urea, on the basis of an extinction coefficient of 15,400 per chromophore in the denatured state [11].

\section{Results}

Integral PC

Treatment of PC trimer with a threefold molar excess of PCMS (on a monomer basis for the protein) results in a partial bleaching of the major absorption $(612 \mathrm{~nm})$ (Fig. 1a). It is accompanied by a minor blue-shift and the formation of a longerwavelength shoulder. The integrated negative band $(612 \mathrm{~nm})$ in the difference spectrum, is about twice as large as the concomitant increase $(655 \mathrm{~nm})$. There is also a distinct increase in the near-uv band. Titration of $\mathrm{PC}$ gives a saturation of the reaction at $1 \mathrm{~mol}$ PCMS per mole PC (Fig. 2a). The same general features are observed in PC trimer containing linker peptides $\left(\lambda_{\max }=629 \mathrm{~nm}\right)$, but here the negative peak in the difference spectrum is located at $632 \mathrm{~nm}$ (data not shown).
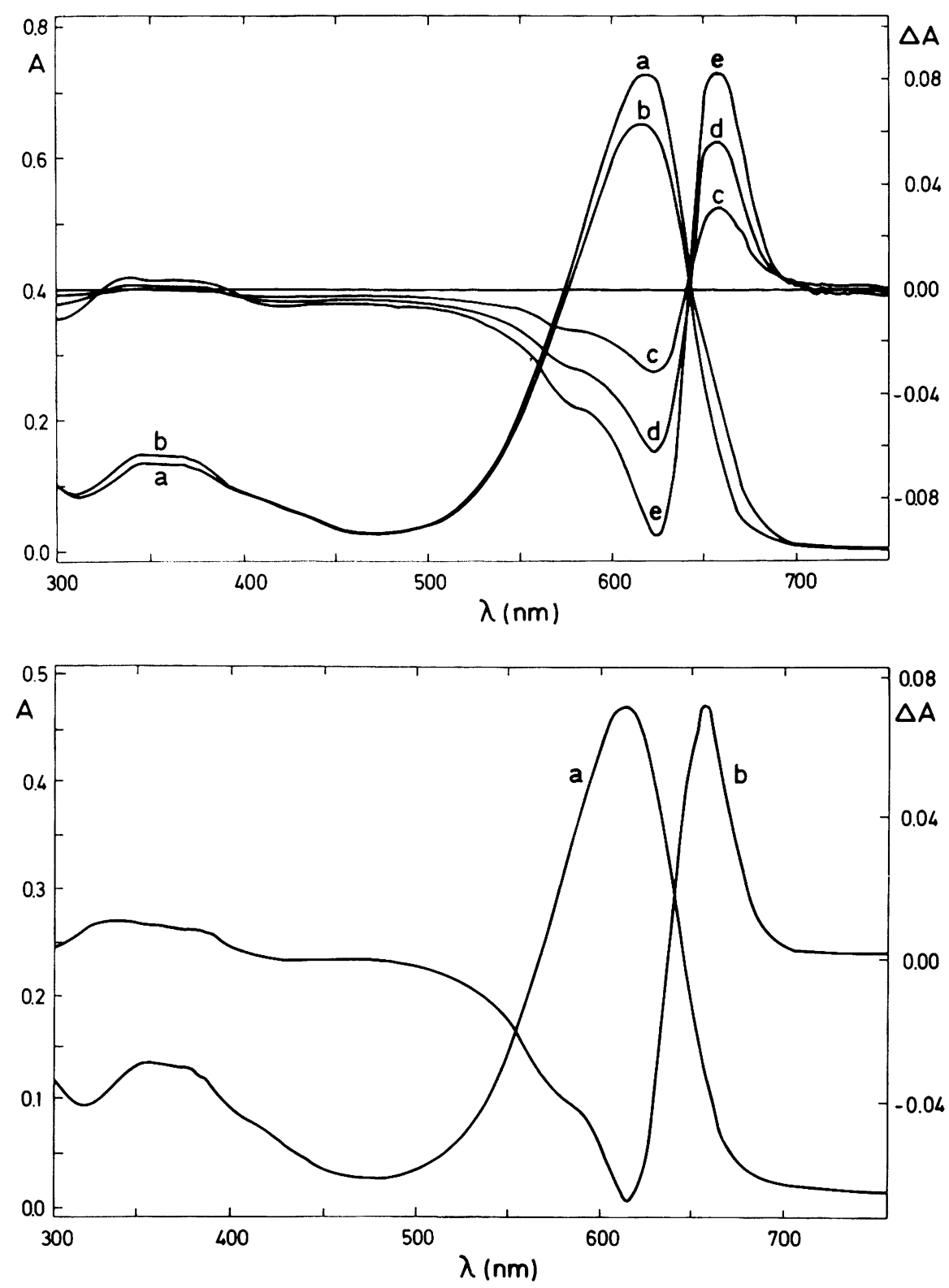

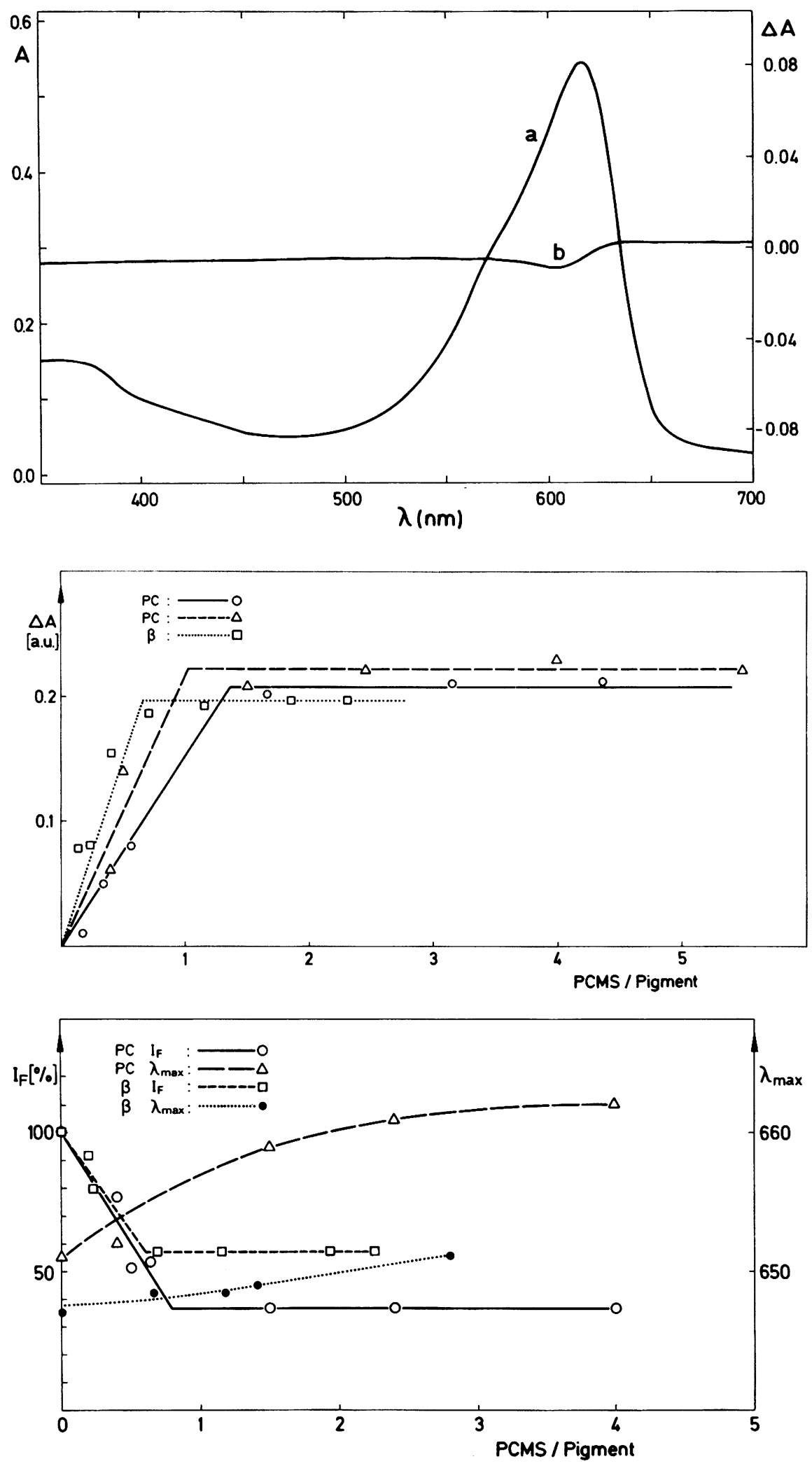

$1 \mathrm{C}$

Fig. 1. Treatment of integral PC-trimer (A), its $\beta$-subunit (B) and its $\alpha$-subunit (C) with PCMS. Absorption (left scales) and absorption difference spectra (right scales). 1 A: PC (4.8 nmol, spectrum a) treated with $13.6 \mathrm{nmol}$ PCMS. Difference spectra recorded after 30 (c), 60 (d) and $100 \mathrm{~min}$ (e), final absorption spectrum (b) $180 \mathrm{~min}$ after addition. 1B: Absorption spectrum (a) of the $\beta$ subunit $(5.66 \mathrm{nmol})$ and final difference spectrum (b) after addition of PCMS ( $9.06 \mathrm{nmol}$, $t=18 \mathrm{~min}$ ). 1C: Absorption spectrum (a) of the $\alpha$-subunit $(6.9 \mathrm{nmol})$ and final difference spectrum (b) after addition of PCMS $(9.1 \mathrm{nmol}$, $t=10 \mathrm{~min}$ ).

$2 \mathrm{~A}$

$2 \mathrm{~B}$

Fig. 2. Titration of integral $P C$ and its $\beta$-subunit with PCMS. $2 \mathrm{~A}$ : Amplitude of the absorption difference signal (maximum-to-minimum).

The absorptions before addition of the reagent were 0.68 $(--), 0.62(--)$ and 0.66 $(\cdots)$. Labels see inset. 2B: Relative fluorescence emission intensities $\left(I_{F}\right.$, left scale) and maxima $\left(\lambda_{\max }\right.$ in $\mathrm{nm}$, right scale). Labels see inset. 
The fluorescence of PC trimer is reduced to a minimum of $35 \%$ of the original value and saturates at $\approx .8 \mathrm{~mol}$ PCMS, its wavelength is shifted by $10 \mathrm{~nm}$ to the red (Fig. $2 \mathrm{~b}$ ). In the CD spectrum, the most notable feature is the development of a shoulder on the red-wing of the long-wavelength band at $650 \mathrm{~nm}$ (data not shown, similar to the $\beta$-subunit shown in Fig. 3).

\section{Subunits}

The spectral changes of the $\beta$-subunit are very similar to the ones observed in trimeric PC. The absorption difference is again centered to the red of the absorption band. The amplitude of the difference spectrum (minimum to maximum) is even larger than $\mathrm{PC}$ in integral (Fig. 1 b), and the reaction saturates at $\approx .65 \mathrm{~mol}$ PCMS (Fig. 2). The fluorescence decreases by $45 \%$, and the amplitude of the red CD maximum by $7 \%$ with a concomitant rise of a shoulder around $650 \mathrm{~nm}$ and an increase of the near-uv band by $17 \%$ (Fig. 3).

The $\alpha$-subunit is essentially unreactive with PCMS (Fig. 1c). There is only a minor feature in the difference spectrum with an intensity of $6 \%$ as compared to the $\beta$-subunit, which probably corresponds to a minor contamination with the latter $(\approx 5 \%$ according to SDS-PAGE). The changes in the fluorescence and the CD spectra are negligible as well (data not shown).

\section{Discussion}

Besides the three cystein residues bound to the chromophores, PC contains only a single free cystein at position 109 on the $\beta$-chain. In the native chromoprotein, this cystein is very close $(\approx 4 \mathrm{~A})$ to the $\beta 82$ chromophore, with an essentially proteinfree hole between them, which is the single binding site for mercurials used for heavy-atom substitution $[20,21]$. The distances to the other chromophores $(\alpha 84, \beta 153)$ both on the same monomer and on the other monomers in the trimer are considerably larger $(\geq 22 \mathrm{~A})$. It is, therefore, expected that the $\beta 82$ chromophore is affected rather specifically upon binding of mercurials. A differential response of individual chromophores has earlier been reported for phycoerythrin [22], but could not be explored further due to lack of structural data at that time.

The saturation behavior in solution confirms the binding of only a single molecule of PCMS both in the PC protomer and its $\beta$-subunit. This is further corroborated by the lack of reaction with the $\alpha$-subunit bearing no free cystein. All spectra can be rationalized by a single chromophore absorbing around $620 \mathrm{~nm}$ in the $\beta$-subunit and the trimer, and around $630 \mathrm{~nm}$ in the linker-containing trimer, respectively, being affected by the reaction of the free cys-109 with PCMS. Two spectrally $[10,13]$, chemically $[10,11]$ and photochemically [12] distinct chromophores have been identified on the $\beta$-subunit

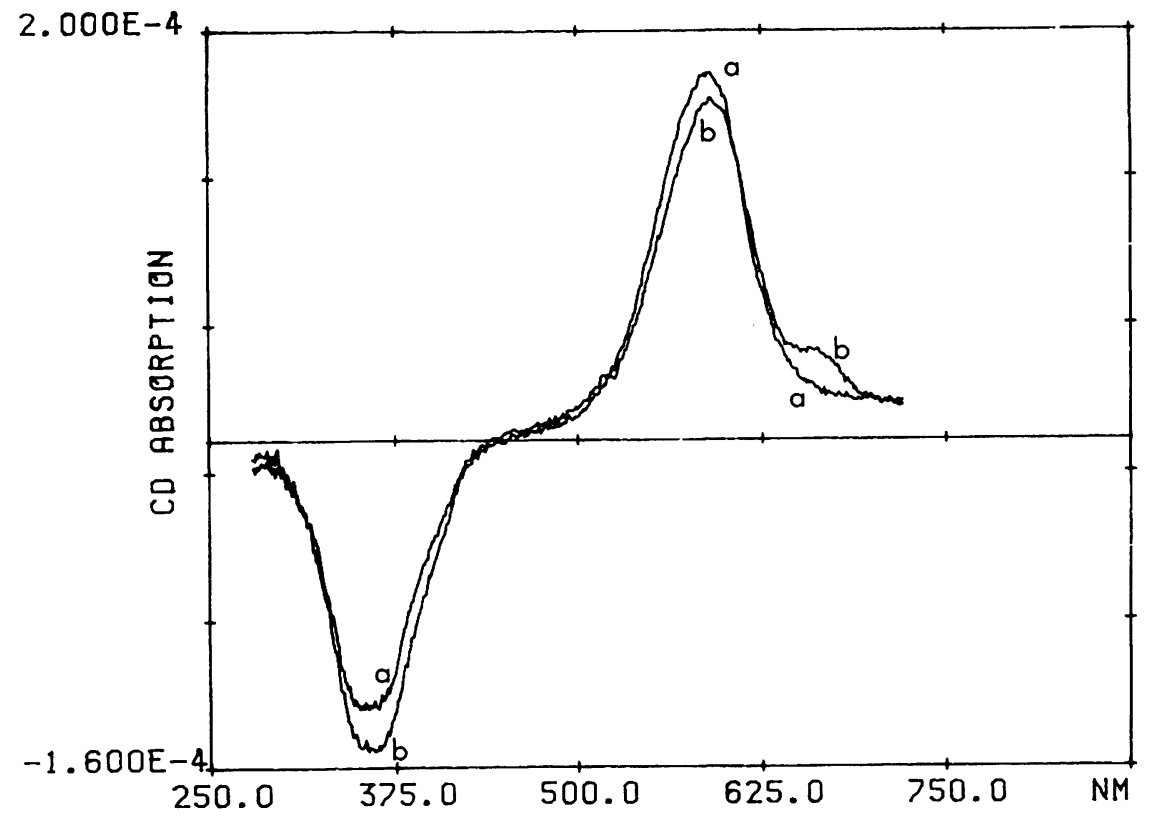

Fig. 3. Circular dichroism spectra of the $\beta$-subunit before (a) and after (b) reaction with PCMS. The spectra have been taken from the samples shown in Fig. $1 \mathrm{~B}$ in absorption (traces $a$ and $b$ ). 
of PC from $M$. laminosus. One of them $(\beta 1)$ absorbs around $620 \mathrm{~nm}$, is only weakly optically active and strongly fluorescent (in the absence of any acceptors), and the reversible photochemistry observed in partly denatured PC or its $\beta$-subunit resides on it. The other one $(\beta 2)$ absorbs below $600 \mathrm{~nm}$, is strongly optically active and weakly fluorescent due to efficient energy transfer to $\beta 1$ and (in integral PC) to the $\alpha$-chromophore(s), and is photochemically inactive. It is clear from the data, that the former chromophore $(\beta 1)$ is the one close to the PCMS binding site and hence identical with $\beta 82$, whereas the latter $(\beta 2)$ is identical with chromophore $\beta 153$. If judged from the absorption changes (increase in the near-uv, decrease in the visible band), the $\beta 82$ chromophore assumes a more helical conformation [11] after PCMS binding.

This assignment relates the photochemical reactivity to the chromophore, $\beta 82$, which is least well defined in the X-ray structure $[20,21]$ and hence probably also least rigidly bound. The data obtained with the linker-containing trimer $\left(\lambda_{\max }=629 \mathrm{~nm}\right)$ also indicate, that the $\beta 82$ chromophore is the one shifted towards longer wavelengths (from $\approx 622$ to $\approx 632 \mathrm{~nm}$ ). These linkers, which are substantial in the spectral modulation and organisation of biliprotein aggregates, are most likely located in the inner

[1] W. Rüdiger, Ber. Deutsch. Bot. Ges. 92, 413 (1979).

[2] E. Gantt, Ann. Rev. Plant Physiol. 32, 327 (1981).

[3] H. Scheer, in: Light Reaction Path of Photosynthesis (F. K. Fong, ed.), pp. 7-45, Springer Verlag, Berlin 1983.

[4] A. N. Glazer, Ann. Rev. Biochemistry 52, 125 (1983).

[5] W. Wehrmeyer, in: Proteins and nucleic Acids in Plant Systematics (U. Jensen and D. E. Fairbrother, eds.), Springer Verlag, Berlin 1983.

[6] W. Kufer, O. Schmid, G. Schmidt, and H. Scheer, Z. Naturforsch. 41 c, 437 (1986).

[7] J. C. Lagarias, A. N. Glazer, and H. Rapoport, J. Am. Chem. Soc. 101, 5030 (1979); see however: H. Rapoport, and A. N. Glazer, in: Optical properties and structure of Tetrapyrroles (G. Blauer and $\mathrm{H}$. Sund, eds.), pp. 411-423, de Gruyter, Berlin, New York 1985.

[8] F. W. J. Teale and R. E. Dale, Biochem. J. 116, 161 (1970).

[9] J. Friedrich, H. Scheer, B. Zickendraht-Wendelstadt, and D. Haarer, J. Amer. Chem. Soc. 101, 1030 (1981).

[10] M. Mimuro, P. Füglistaller, R. Rümbeli, and $H$. Zuber, Biochim. Biophys. Acta 848, 155 (1986).

[11] W. Kufer and H. Scheer, Hoppe-Seyler's Z. Physiol. Chem. 360, 935 (1979).

[12] W. John, R. Fischer, S. Siebzehnrübl, and H. Scheer, in: Antennas and Reaction Centers of Photosynthetic Bacteria: Structure, Interaction and Dynamics (M. E. Michel-Beyerle, ed.), Springer Verlag, Berlin 1985. hole of the doughnut-shaped tri- and hexamers $[4,5]$. In PC, the $\beta 82$ chromophore partly extends into this hole, which nicely fits with its spectral shift upon binding of linker peptides.

Treatment with the mercurial, PCMS, thus allows a straightforward chromophore assignment in PC and its aggregates. It should be useful as well with other biliproteins in view of the increased structural data available [1-5]. Interestingly, there are also large differences among the binding kinetics of PCMS to the different PC aggregates including phycobilisomes. This may be helpful in topological studies and is currently explored.

\section{Acknowledgements}

This work was supported by the Deutsche Forschungsgemeinschaft, Bonn. We are grateful for many stimulating discussions with and the provision of unpublished material by T. Schirmer and R. Huber (Martinsried). The large-scale culture of $M$. laminosus by $\mathrm{G}$. Reng at the Gesellschaft für biotechnologische Forschung (Stöckheim) is acknowledged.

Note added in proof: The amino acid residue numbering of the $\beta$-subunit has been used differently in the literature [14, 20]. The one used corresponds to the original sequence data [14].

[13] K. Sauer, H. Scheer, and P. Sauer, Photochem. Photobiol., submitted; in part published in Proc. VII Int. Congr. Photosynthesis (J. Biggins, ed.), p. I. 1. 139, Martinus Nijhoff, Dordrecht.

[14] G. Frank, W. Sidler, H. Widmer, and H. Zuber, H. Hoppe-Seyler's Z. Physiol. Chem. 359, 1491 (1978).

[15] P. Freidenreich, G. S. Apell, and A. N. Glazer, J. Biol. Chem. 253, 212 (1978).

[16] G. D. Offner, A. S. Brown-Mason, M. M. Ehrhardt, and R. F. Troxler, J. Biol. Chem. 256, 2167 (1981).

[17] R. F. Troxler, M. M. Ehrhardt, A. S. Brown-Mason, and G. D. Offner, J. Biol. Chem. 256, 2176 (1981).

[18] T. J. Pilot and J. L. Fox, Proc. Natl. Acad. Sci. USA 81, 6983 (1984).

[19] R. Lorimier, D. A. de Bryant, R. D. Porter, W. Y. Liu, E. Jay, and S. E. Stevens jr., Proc. Natl. Acad. Sci. USA 81, 7946 (1984).

[20] T. Schirmer, W. Bode, R. Huber, W. Sidler. and H. Zuber, J. Mol. Biol. 184, 257 (1985).

[21] T. Schirmer, R. Huber, M. Schneider, W. Bode, M. Miller, and M. L. Hackert, J. Mol. Biol. 188, 651 (1986).

[22] J. Pecci, and E. Fujimori, Biochem. Biophys. Acta 154, 332 (1968).

[23] R. W. Castenholz, Schweizer Z. Hydrol. 35, 538 (1970).

[24] 3001 mass cultures in the phototrophic fermenter at the Gesellschaft für Biotechnologische Forschung, 3301 Stöckheim, FRG. 